\title{
INFLUENCE OF THE THICKNESS OF JOINED ELEMENTS ON LAP LENGTH OF ALUMINIUM ALLOY SHEET BONDED JOINTS
}

\author{
Anna Rudawska ${ }^{1}$ \\ 1 Department of Production Engineering, Faculty of Mechanical Engineering, Lublin University of Technology, \\ Nadbystrzycka 36, 20-618 Lublin, Poland, e-mail: a.rudawska@pollub.pl
}

Received: 2015.05 .12 Accepted: 2015.08.05 Published: 2015.09.01

\begin{abstract}
This work features the results of experimental research in determining the limiting length of the bonded single-lap joint of materials of the same thickness, different thicknesses and of hybrid systems of different aluminium alloy sheets. The length of the bonded lap joint is just one of the structural features, critical to the strength of bonded joints, this length depending on the thickness and type of the bonded elements. In the case of single-lap bonded joints there is a limiting lap length exceeding of which should not increase the strength of such joints. This is why the length of a bonded lap joint is critical in terms of strength and application concerns. The length of the lap is not always reflected in practice due to simplification of the analytical relations. What is required is experimental verification of the derived theoretical relations. The tested materials are aluminium alloy sheets, widely used in the machinery, aviation and construction industries.
\end{abstract}

Keywords: aluminium and alloys, single-lap bonded joints, strength.

\section{INTRODUCTION}

Due to their advantages, bonded joints are widely used in many industries [1-3]. In some cases bonding is the only method of joining materials of different properties and/or geometrical dimensions. Bonded aluminium alloy joints are often used in aviation, construction engineering and machine industry. Extensive information about the analysis of aluminium sheet bonded joints is presented in [4-7], where the bonding strength is also frequently studied.

There are many structural and processing factors which influence the strength of a bonded joint [8-12]. One of the structurally-critical factors which affects the strength is the length of the bonding joint $[1-3,11]$. The literature provides relations used to calculate the length [11]. Some structures feature joints of materials having different thicknesses and properties, and may have different mechanical characteristics. Many bonded joints require determining the bonded lap joint length due to strength and cost-effectiveness con- siderations. The aspect of strength is related to the limiting length of the lap, exceeding which should not increase the strength. If this length is known, the bonded joint can be designed properly. The questions of cost-effectiveness concerns, among the other factors, the consumption of bonding adhesives for the joints, especially if relatively large bonded joint surfaces are involved. The majority of structural bonding adhesives are expensive, making it crucial to determine the joint length of bonded materials with respect to the strength requirements. It is unnecessary to create bonded joints that are thicker (compared with the optimum thickness) or longer without justification.

The subject of the analyses described in this work involves single-lap bonded joints of selected structural materials, i.e. aluminium alloy sheets. Single-lap bonded joints are often used in structures due to their strength characteristics, and a number of issues related to the analysis of such joints are presented in the references [1, $12,13]$. The sheets used included pieces of equal and different thickness. A system was also stud- 
ied involving the same basic material, i.e. aluminium alloy sheets, but of various alloy types and thicknesses.

\section{BONDED JOINT LAP LENGTH}

One of the structural factors included in the design of bonded lap joints is the lap length of the joint. These joints feature a limiting lap length, the exceeding of which according to Volkersen's theory should not result in any further increase in the strength of the bonded joint $[2,11]$. Knowing the limiting lap length is also extremely important for applications as it allows, for example, the indirect calculation of the limiting thickness of the joined elements.

Bonded joints having a lap length smaller than the limiting length $\left(1_{1}<1_{\mathrm{gr}}\right)$ have a shearing stress $\tau$ across its entire length and increasing non-linearly from the middle of the lap (Fig. 1a). For bonded joints with a lap length larger than the limiting length $\left(1_{1}>1_{g r}\right)$, the shearing stress at a certain central point of the lap is close to zero (see Fig. 1c), and indicates that the lap length is too large. Calculation of the lap joints, including $1_{\mathrm{gr}}$ is closely related to the stress distribution along the lap length and the stress concentration coefficient.

The limit lap length determined is the preliminary approximate length assumed for the design and is usually verified by testing. The following relation (1) can be used to perform analytical determination of the limit lap length of identical elements [11]:

$$
l_{g r} \geq 5 \sqrt{\frac{E g g_{k}}{2 G_{k}}}
$$

where: E - Young's modulus of the bonded elements,

$\mathrm{g}$ - thickness of bonded elements,

$\mathrm{g}_{\mathrm{k}}$ - adhesive joint thickness,

$\mathrm{G}_{\mathrm{k}}$ - shear modulus of the adhesive.

Some information of determination of the limit lap length are presented in the references $[3$, $11,16]$.

\section{METHODOLOGY}

\section{Materials}

The study included bonded joints of 2024T3, 2024-TO (EN AW 2024) and 7075-TO (EN AW 7075) [17-19]. aluminium alloys of different thicknesses. The surfaces of the sheets were plated. In one of Polish aircraft factory these kinds of sheets are used. A lot of structures are made of these thicknesses of sheets. Detailed plate chemical composition is given in the standard EN-4400-2. The symbol T means "Tempers" and it means Heat-Treated: T3 - solution heat-treated and then cold worked [17, 18]. A temper defined the state $\mathrm{O}$ as annealed - applies to products which gain specific properties in the thermal treatment process [19].

\section{Bonded joints tested}

A diagram of the examined bonded joint is shown in Figure 2. The dimensions of the samples are $b=20 \mathrm{~mm}$ and length $1=100 \mathrm{~mm}$. The thickness of adhesive layer $\mathrm{g}_{\mathrm{k}}$ is $0,1 \mathrm{~mm}$.

Specific types of bonding joints, the thickness of the joined elements $\left(g_{1}\right.$ and $\left.g_{2}\right)$ and the analysed bonded joint lap lengths $\left(l_{z}\right)$ are shown in Table 1. a)

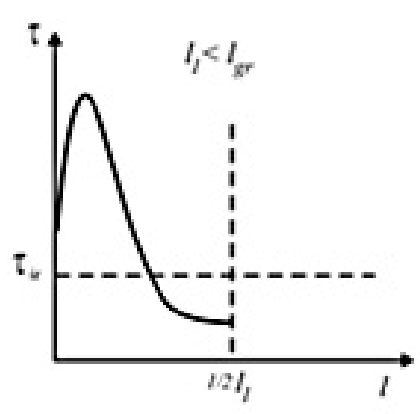

b)

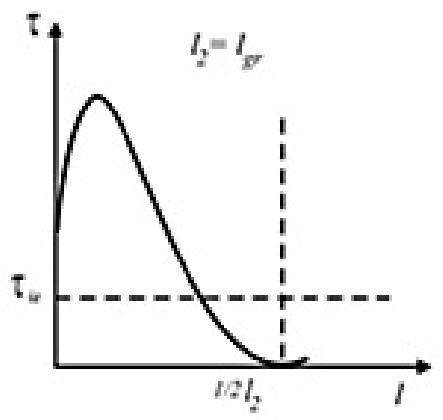

c)

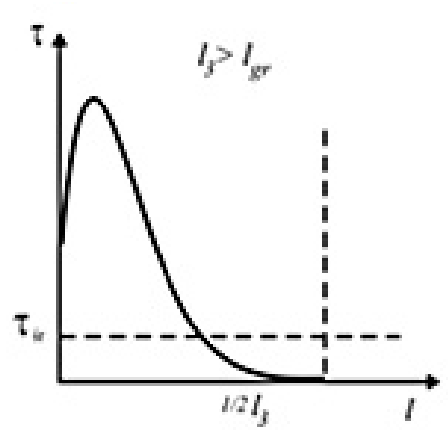

Fig. 1. The distribution of the shearing stress in bonded joints loaded for shear in relation to the lap length: a) lap length is smaller than limit lap length, b) lap length is equal limit lap length, c) lap length is bigger than limit lap length; where: $t$ - shear stress, $t_{s r}$ - mean shear stress, $1_{1}, 1_{2}, 1_{3}$ - lap length, $1_{\mathrm{gr}}-$ limit lap length $[11,15]$ 


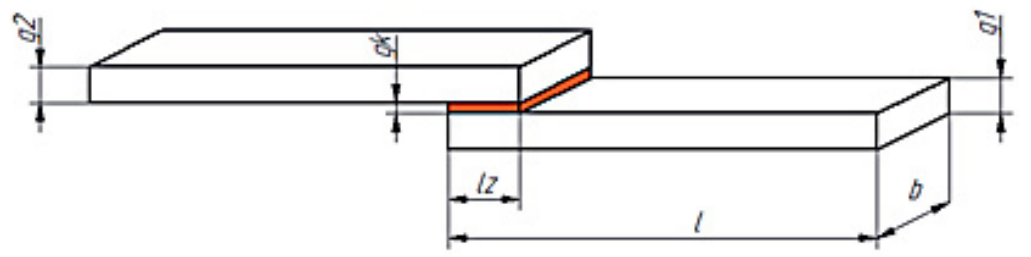

Fig. 2. Diagram of a single-lap bonded joint

\section{Lap length}

In case of the bonding of elements of various thicknesses, the joints were made with three different bonded joint lap lengths, including:

1) thinner elements;

2) thicker elements;

3) intermediate thickness elements.

The lap length values depended on the bonded joint type and thickness, and are shown in Table 1. The analytical lap length of identical elements determination from equation (1) is smaller than limit lap length, but these thicknesses of joined sheets and the first and the second lap length) are used in one of aviation factory. These lap lengths are bigger than limit lap length (see Table 1: 1), but during the tests the same shape of bonded joints of the same thickness of joining sheets as in aviation factory was preserved.

The same surface reinforcement was used for the bonded joints type of analysed aluminium alloy sheets (Table 1, no. 3), i.e. TO, and the surfaces of both sheet types were plated. The length of the bonded joint lap of the analysed joints was determined from the relation (1).

\section{Preparation of adhesive joint}

The accepted surface preparation method of the tested material involved degreasing with Loctite 7063 at an ambient temperature of $20 \pm 2{ }^{\circ} \mathrm{C}$. Loctite 7063 is a degreasing agent (solvent) and cointains: isoparaffin, dimethoxymethane and ethanol blend [20]. It is dedicated for cleaning and degreasing of surfaces. The surfaces were cleaned by spraying and cleaning process was repeated tree times. After several minutes (about 3 minutes) the adhesive was applied directly after on one of the joined surfaces and later second joined sheet was placed on the first. The bonding adhesive used was Loctite 3430 (Fig. 3a) [20]. This adhesive is a two component, clear epoxy adhesive which cures rapidly at room temperature after mixing and in laboratory test is useful adhesive. It is a general purpose adhesive which develops high strength on a wide range of substrates.

The adhesive components were mixed with a static mixer (Fig. 3b) and the adhesive was applied with an applicator located directly on the package and by using manual dispensing applicator [20]. This adhesive was applied as quickly as possible after mixing to one surface to be joined because the working life of the mixed adhesive is $\leq 4$ minutes at $22{ }^{\circ} \mathrm{C}$. Higher temperature and larger quantities will shorten this working time.

Curing conditions were following: temperature $20 \pm 2{ }^{\circ} \mathrm{C}$, curing time $48 \mathrm{~h}$, humidity $26 \%$, pressure $0.02 \mathrm{MPa}$.

Some properties of Loctite 3430 adhesive are given in Table 2.

Figure 4 presents bonded joint of aluminium sheets after joining process. After 48 hours the bonded joints were tested in strength device Zwick/Roell 100.

Table 1. Bonded joints types for 2024-T3 aluminium alloy sheets

\begin{tabular}{|c|c|c|c|}
\hline Item no. & Tested joint types & Thickness $g$ of joined sheets [mm] & Length $I_{z}$ of the bonded joint lap [mm] \\
\hline \multirow{3}{*}{1} & \multirow{3}{*}{ 2024-T3 aluminium alloy sheet } & \multirow{3}{*}{$\begin{array}{l}g_{1}=0.64 \\
g_{2}=1.00\end{array}$} & 24 \\
\hline & & & 27 \\
\hline & & & 30 \\
\hline \multirow{3}{*}{2} & \multirow{3}{*}{ 7075-TO aluminium alloy sheet } & \multirow{3}{*}{$\begin{array}{l}g_{1}=0.80 \\
g_{2}=1.00\end{array}$} & 27 \\
\hline & & & 28.5 \\
\hline & & & 30 \\
\hline 3 & $\begin{array}{l}\text { 2024-TO aluminium alloy sheet } \\
\text { and } 7075 \text {-TO aluminium alloy sheet }\end{array}$ & $\begin{array}{l}g_{1}=0.64 \\
g_{2}=1.00\end{array}$ & 27 \\
\hline
\end{tabular}




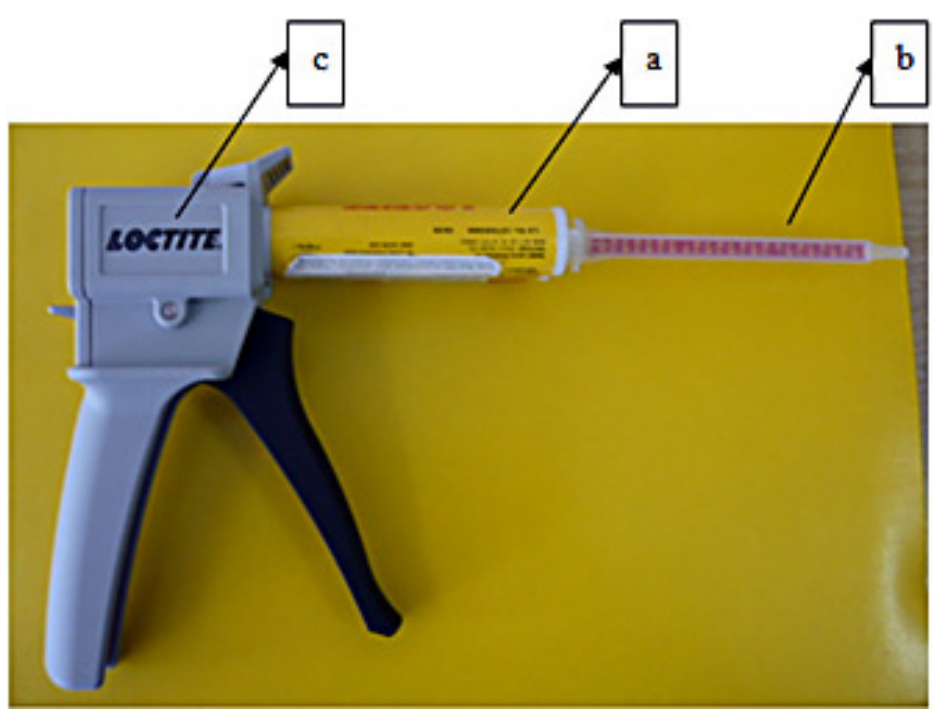

Fig. 3. The scheme of applied adhesive device: a) adhesive package, b) static mixer and applicator, c) Loctite 96001 Manual Dispensing Applicator.

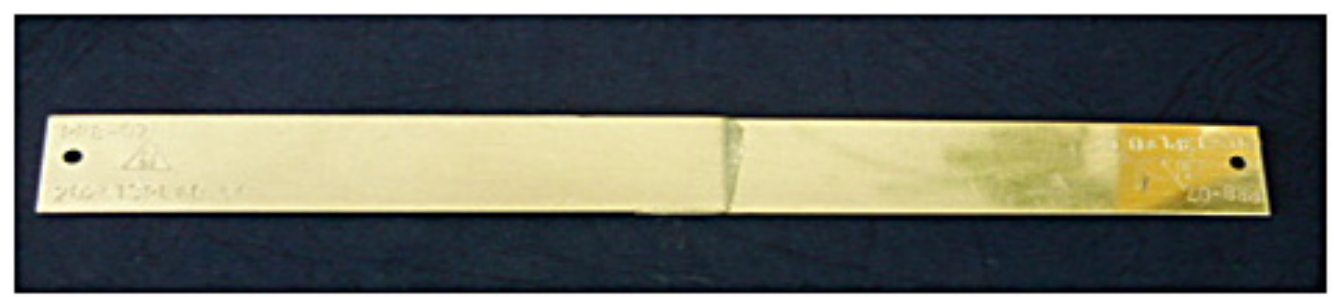

Fig. 4. Bonded joint of aluminium sheets

Table 2. Some physical properties of Loctite 3430 adhesive [21]

\begin{tabular}{|l|l|c|}
\hline \multicolumn{2}{|c|}{ Characteristics } & $36 \mathrm{~N} / \mathrm{mm}^{2}$ \\
\hline \multirow{4}{*}{$\begin{array}{l}\text { Physical properties (of cured material for 7 days } \\
\text { at } 22{ }^{\circ} \mathrm{C}, 1.2 \mathrm{~mm} \text { thick samples) }\end{array}$} & Tensile Strength, ISO 527-3 & $3,210 \mathrm{~N} / \mathrm{mm}^{2}$ \\
\cline { 2 - 3 } & Tensile Modulus, ISO 527-3 & $65 \mathrm{~N} / \mathrm{mm}^{2}$ \\
\cline { 2 - 3 } & Compressive Strength, ISO 604 & $2 \%$ \\
\cline { 2 - 3 } & Elongation, ISO 527-3 & 70 \\
\cline { 2 - 3 } & Shore Hardness, ISO 868, Durometer D & 70 \\
\hline
\end{tabular}

\section{RESULTS}

This section features the results of the tests supplemented with explanations, while the summary presents the conclusions and observations made following the statistical analysis of these results; the analysis itself is contained in section 5. For each configuration of bonded joints of aluminium sheets were made 10-12 samples of bonded joints, but due to some problems during preparing of joints, various numbers of tests were considered during statistical analysis. In each cases of test, two or four extreme results were eliminated.

Figure 5 gives the results of the bonded joint strength tests for the 2024-T3 aluminium alloy sheets with various thicknesses of joined elements for various lengths of the bonded joint lap (see Table 1, item 3). The strength of adhesive joints is described as average shear stress in [N] to relation adhesive area $\left[\mathrm{mm}^{2}\right]$.

The test results allow the conclusion that the highest bonded joint strength of 2024-T3 aluminium alloy sheets of various sheet thicknesses was achieved for the shortest lap length $(24 \mathrm{~mm})$, while the lowest strength was achieved for the longest lap length $(30 \mathrm{~mm})$. The shortest lap length was assumed for the smaller thickness of joined elements, i.e. $0.64 \mathrm{~mm}$. The longest lap length was included for the thicker tested, i.e. $1.00 \mathrm{~mm}$. The analysis of the results indicate that when two elements of different thickness are bonded it is 


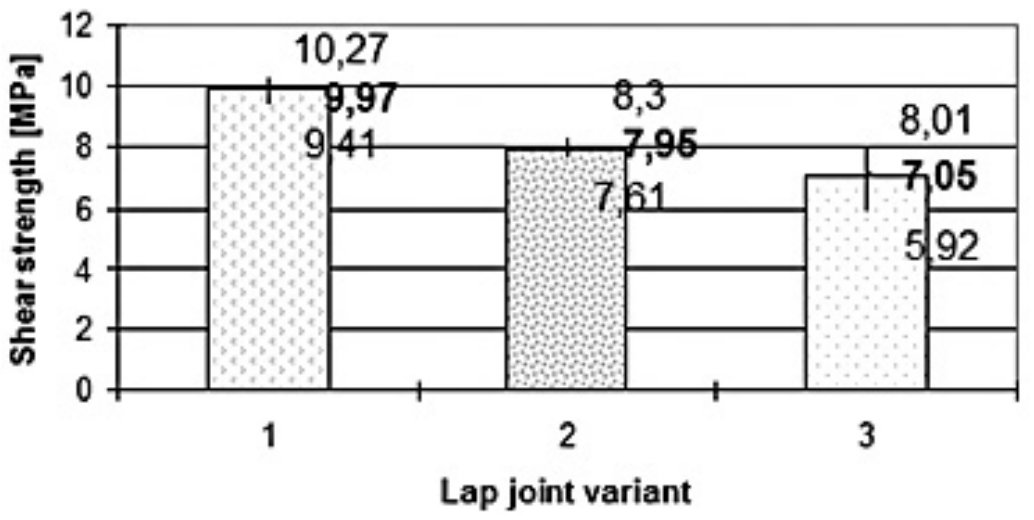

Fig. 5. The bonded joint strength for the 2024-T3 aluminium alloy sheets, with different thicknesses, where $\mathrm{g}_{1}=0.64$ and $\mathrm{g}_{2}=1.00: 1$ ) lap length $\mathrm{l}=24 \mathrm{~mm}$; ) lap length $\mathrm{l}=27 \mathrm{~mm} ; 3$ ) lap length $\mathrm{l}=30 \mathrm{~mm}$

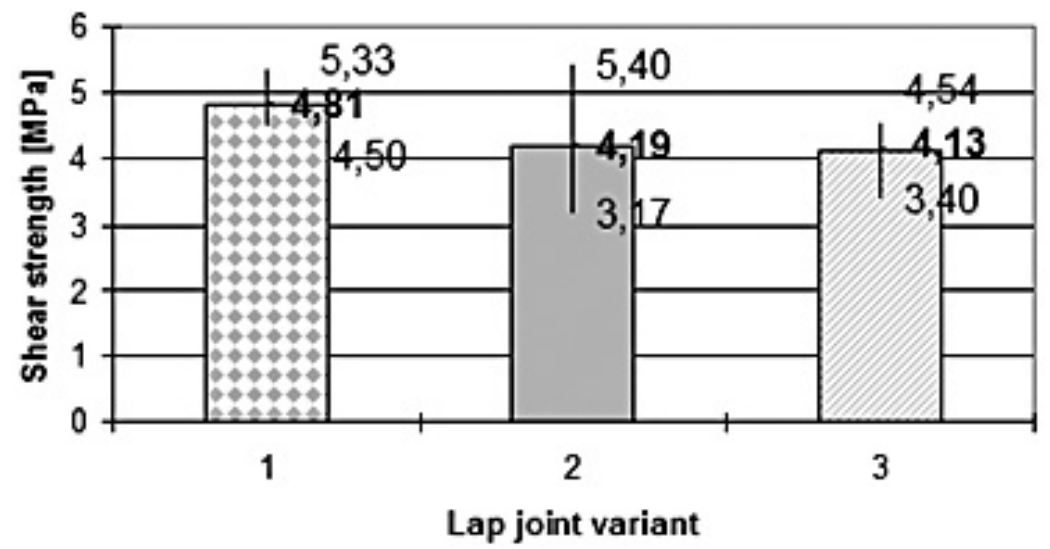

Fig. 6. Bonded joint strength for the 7075- TO aluminium alloy sheets with various thicknesses of joined elements, where $g_{1}=0.80$ and $g_{2}=1.00: 1$ ) lap length $1=27 \mathrm{~mm} ; 2$ ) lap length $1=28.5 \mathrm{~mm}$; $)$ lap length $=30 \mathrm{~mm}$

advisable to assume the shorter lap length defined for the smaller thickness of the joined elements for the sake of higher strength.

The strength test results for the lap length of the 7075-T0 aluminium alloy bonded joints with different sheet thicknesses is presented in Figure 6.

Based on the test results (see Fig. 6) the highest strength was achieved in the case of bonded joints with the shortest lap length $(1=27 \mathrm{~mm})$, which was determined for the thinner of the joined elements $(\mathrm{g}=0.80 \mathrm{~mm})$. The least strength occurred for those bonded joints with the largest lap length $(1=30 \mathrm{~mm})$ with the thicker of the bonded elements $(1=1.00 \mathrm{~mm})$. The thickness difference between the joined sheets was $0.2 \mathrm{~mm}$.

The strength test results for the systems 2024TO and 7075-TO aluminium alloy sheets of different thicknesses are given in Table 3.

The comparison of the strength test results for the system of 2024-TO and 7075-TO aluminium alloy sheets of different thicknesses with the results achieved for the bonded joints of specific sheet types shows that the systems of 2024 and 7075 aluminium alloy sheets exhibit lower strength bonded joints (3.78 MPa, see Table 3) than for bonded joints of the $1.00 \mathrm{~mm}$ thick 7075 TO aluminium alloy sheets $(4,54 \mathrm{MPa})$. In the case of the bonded joints of the $0.64 \mathrm{~mm}$ thick 2024-TO aluminium alloy sheets and a lap length of $24 \mathrm{~mm}$, the materials were failed; however, the bonded joint was not failed (see Fig. 7).

In the light of this case, it seems favourable to bond different aluminium alloys of different thickness, since this may result in a higher strength. Moreover, the results for this joint may prove that the surface treatment method and the bonding adhesive were chosen favourably for the assumed joint lap length (for the thickness values analysed). Surface treatment of aluminium sheets is connected with strain-hardening aluminium tempers [29]. These sheets are in the O temper, while the other sheets are in T3 temper. The tensile strength Rm (Table 1) of 7075-TO aluminium sheets is higher than 2024-TO aluminium sheets.

During the preparation of the specimen the adhesive was not confined but was allowed to 
Table 3. Bonded joint strength for various aluminium alloy sheets

\begin{tabular}{|c|c|c|c|c|c|}
\hline Item no. & Bonded joint type & $\begin{array}{c}\text { Surface area } \\
{\left[\mathrm{mm}^{2}\right]}\end{array}$ & \multicolumn{2}{|c|}{$\begin{array}{c}\text { Bonded joint failure force } \\
\text { avg } \mathrm{Pt}[\mathrm{N}]\end{array}$} & $\begin{array}{c}\text { Strength } \\
\text { avg [MPa] }\end{array}$ \\
\hline \multirow{9}{*}{\begin{tabular}{|l|} 
No. 3 \\
of Table 1
\end{tabular}} & \multirow{9}{*}{$\begin{array}{l}\text { 7075-TO aluminium alloy sheet } \\
\mathrm{g}=1 \mathrm{~mm} \\
\text { 2024-TO aluminium alloy sheet } \\
\mathrm{g}=0.64 \mathrm{~mm}\end{array}$} & \multirow{9}{*}{$\begin{array}{l}B=20 \mathrm{~mm} \\
\operatorname{Llim}=27 \mathrm{~mm} \\
S=540 \mathrm{~mm}^{2}\end{array}$} & 1973.50 & \multirow{6}{*}{2043.60} & \multirow{9}{*}{3.78} \\
\hline & & & 2029.34 & & \\
\hline & & & 1974.91 & & \\
\hline & & & 1972.97 & & \\
\hline & & & 2297.96 & & \\
\hline & & & 2012.91 & & \\
\hline & & & Test repetition & 6 & \\
\hline & & & Deviation standard & 126.86 & \\
\hline & & & Variance & 16093.03 & \\
\hline
\end{tabular}

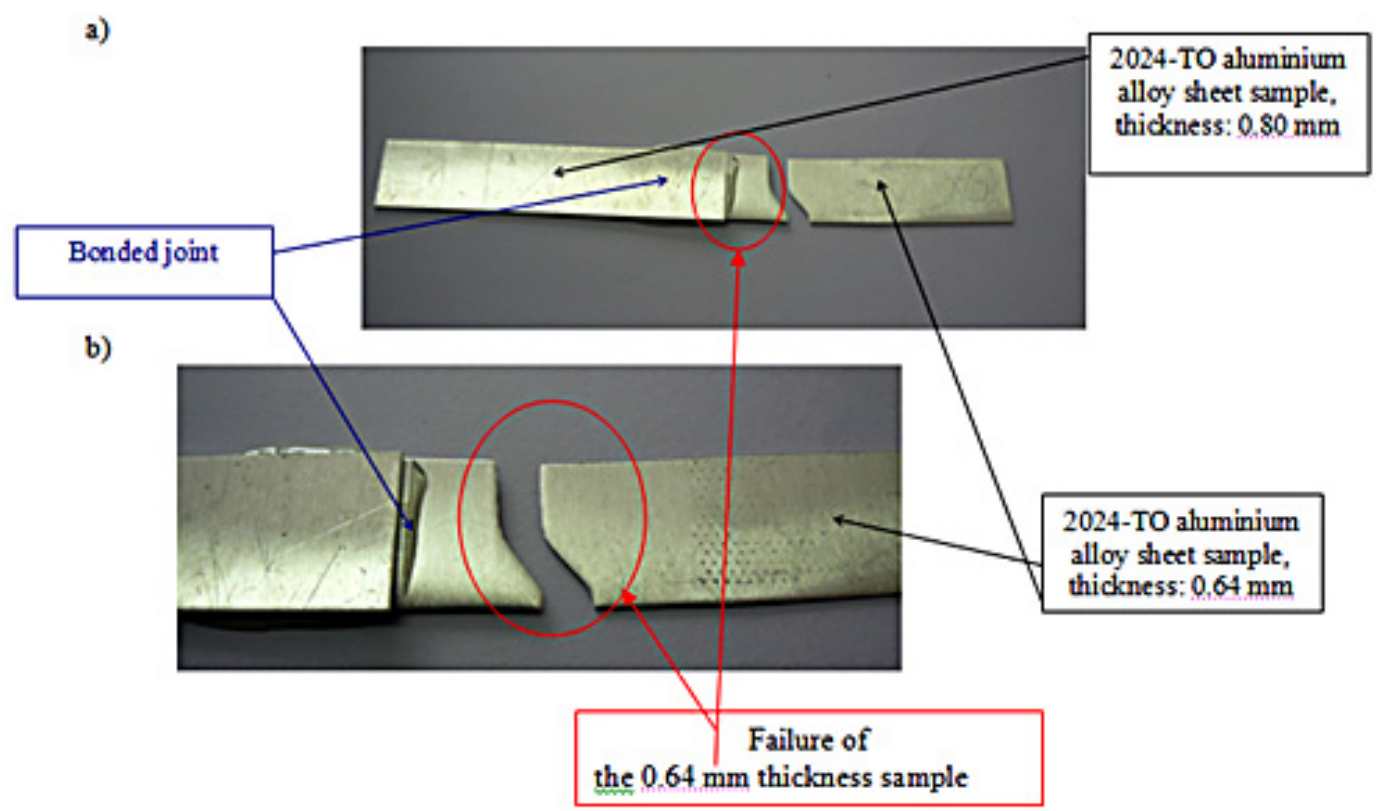

Fig. 7. An example of a failure a system bonded joint made of 2024-TO and 7075-TO aluminium alloy sheets ( $0.64 \mathrm{~mm}$ and $1.00 \mathrm{~mm}$ thick respectively), where one of the bonded joint materials was destroyed, i.e. the sample made of the 2024-PL alloy, $g=0.64 \mathrm{~mm}$; a) general view, b) detailed view

flow out of superposition zone. Some information about the shape of lap zone and the effect of the preformed angle on the stress distribution of a bonded joint are reported i.e. in [32, 33].

Figure 8 includes the strength test results for the bonded joints with equal lap lengths of $27 \mathrm{~mm}$.

The results of the strength tests for the aluminium sheet bonded joints in various systems with a lap length of $27 \mathrm{~mm}$ show that the highest strength was achieved for the joints of the 2024$\mathrm{T} 3$ sheets of various thicknesses, where the length of the lap was determined for the thinner of the bonded elements. The lowest strength value was achieved for the bonded joint of the 2024-TO aluminium alloy sheet with a thickness of $0.64 \mathrm{~mm}$ and the 7075-TO aluminium alloy sheet with a thickness of $1.00 \mathrm{~mm}$.
Figure 9 includes the comparison of the strength test results for the bonded joints with equal lap lengths of $30 \mathrm{~mm}$.

Based on the results (for the lap length of 30 $\mathrm{mm}$, see Fig. 9), it is noted that the highest strength was achieved for bonded joints of the 2024-T3 aluminium alloy sheets of different thicknesses $(0.64$ and $1.00 \mathrm{~mm})$, amounting to $7.35 \mathrm{MPa}$. The lowest strength was noted for the bonded joints of the 7075-TO aluminium alloy sheets of different thicknesses $(0.80$ and $1.00 \mathrm{~mm})$, amounting to $4.13 \mathrm{MPa}$. It is also observed that different systems of the 2024-T3 alloy bonded joints give a much higher strength than the bonded joints of the 7075-TO alloys (also in different systems). It may be theorised that the reinforcement of the surface layer influences the strength of the bonded joints aluminium sheets. The 2024-T3 aluminium alloy 


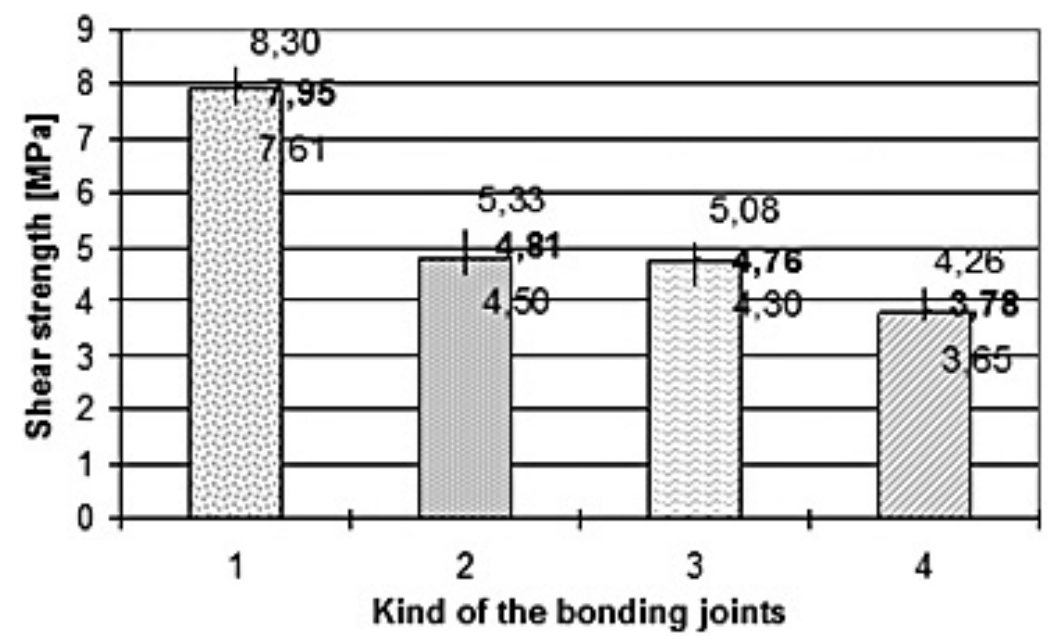

Fig. 8. Bonded joint strength for aluminium alloy sheets with the lap length of $27 \mathrm{~mm}$; the used systems:

1) 2024-T3 aluminium alloy sheet, $\mathrm{g}=0.64 \mathrm{~mm}$ and $\mathrm{g}=1.00 \mathrm{~mm}$; 2) 7075 -TO aluminium alloy sheet, $\mathrm{g}=0.80 \mathrm{~mm}$ and $\mathrm{g}=1.00 \mathrm{~mm}$; 3) 7075-TO aluminium alloy sheet, $\mathrm{g}=0.80 \mathrm{~mm}$; 4) 2024-TO aluminium alloy sheet, $\mathrm{g}=0.64 \mathrm{~mm}$, and 7075-TO aluminium alloy sheet, $\mathrm{g}=1.00 \mathrm{~mm}$.

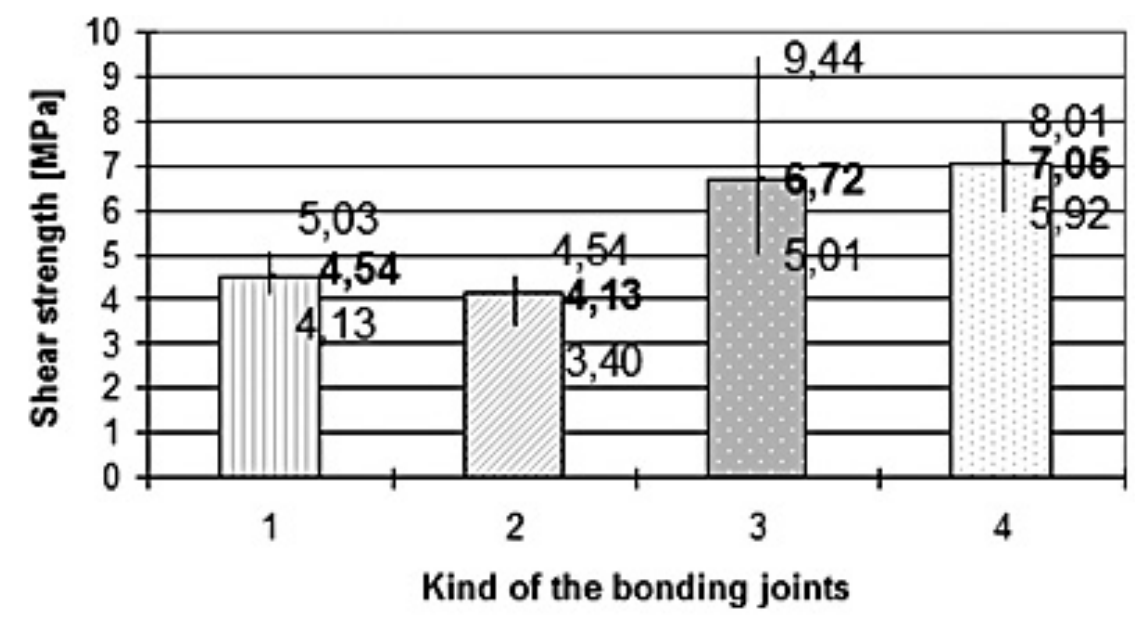

Fig. 9. Bonded joint strength for aluminium alloy sheets with the lap length of $30 \mathrm{~mm}$; the used systems: 1) 7075 TO aluminium alloy sheet, $g=1.00 \mathrm{~mm}$; 2) 7075-TO aluminium alloy sheet, $\mathrm{g}=0.80 \mathrm{~mm}$ and $\mathrm{g}=1.00 \mathrm{~mm} ; 3$ ) 2024-T3 aluminium alloy sheet, $\mathrm{g}=1.00 \mathrm{~mm}$; 4) 2024-T3 aluminium alloy sheet, $\mathrm{g}=0.64 \mathrm{~mm}$ and $\mathrm{g}=1.00 \mathrm{~mm}$

sheet has a higher surface reinforcement than the 7075-TO aluminium alloy sheet, which results in the higher strength of the 2024-T3 alloy sheet bonded joints. However this thesis cannot be fully confirmed at this stage. The results form the basis for further investigation, and testing will be continued.

\section{STATISTICAL VERIFICATION OF THE TEST RESULTS}

The test results were statistically verified with the use of various algorithms [22, 23]. The development of the data involved tests of significance to compare the mean values of the tested trait in two general populations. The test included the first type error, i.e. rejection of the tested hypothesis if it is true. The first type error is called the level of significance and was assumed at $\alpha=0.05$. The samples are to be treated as small due to the fact that the set included up to 30 elements. The following samples were used: t-Student, Snedecor-Fisher F and the applicable statistical models. The t-Student statistical test model included the comparison of means with equal sample variance.

The statistical analysis was the basis for the formulation of conclusions. The results of testing the hypothesis of equality of two means with the use of the above model for the analysed variants of bonded joints is listed in Table 4. The statistical analysis included the test results presented in Figures 5, 6, 8 and 9. 
Table 4. Results of testing the hypothesis of equality of two means with the use of t-Student statistical model at the level of significance of $\mathrm{a}=0.05$

\begin{tabular}{|c|c|c|c|c|c|c|}
\hline Figure & F statistic value & Critical value $\mathrm{F}_{\alpha}$ & Conclusion & T statistic value & Critical value $t_{\alpha}$ & Conclusion \\
\hline Fig. 5:1-2 & 5.05 & 2.22 & $\mathrm{~S}^{2}{ }_{1}=\mathrm{S}^{2}{ }_{2}$ & 1.813 & 4.777 & $\bar{X}_{1} \neq \bar{X}_{2}$ \\
\hline Fig. 5:2-3 & 5.05 & 1.04 & $\mathrm{~S}^{2}{ }_{1}=\mathrm{S}_{2}{ }_{2}$ & 1.813 & -0.429 & $\bar{X}_{1}=\bar{X}_{2}$ \\
\hline Fig. 6:1-2 & 5.05 & 1.19 & $\mathrm{~S}^{2}{ }_{1}=\mathrm{S}_{2}{ }_{2}$ & 1.813 & 0.9272 & $\bar{X}_{1}=\bar{X}_{2}$ \\
\hline Fig. 6:2-3 & 5.05 & 2.46 & $\mathrm{~S}^{2}{ }_{1}=\mathrm{S}_{2}{ }_{2}$ & 1.813 & -0.357 & $\bar{X}_{1}=\bar{X}_{2}$ \\
\hline Fig. 6:1-3 & 5.05 & 1.46 & $\mathrm{~S}^{2}{ }_{1}=\mathrm{S}_{2}{ }_{2}$ & 1.813 & 0.762 & $\bar{X}_{1}=\bar{X}_{2}$ \\
\hline Fig. 8:1-2 & 5.05 & 1.65 & $\mathrm{~S}^{2}{ }_{1}=\mathrm{S}^{2}{ }_{2}$ & 1.813 & 15.943 & $\bar{X}_{1} \neq \bar{X}_{2}$ \\
\hline Fig. 8:2-3 & 5.05 & 1.07 & $\mathrm{~S}^{2}{ }_{1}=\mathrm{S}_{2}{ }_{2}$ & 1.813 & 0.235 & $\bar{X}_{1}=\bar{X}_{2}$ \\
\hline Fig. 8:3-4 & 5.05 & 2.76 & $\mathrm{~S}_{1}^{2}=\mathrm{S}_{2}^{2}$ & 1.813 & 5.217 & $X_{1} \neq X_{2}$ \\
\hline Fig. 9:1-2 & 5.05 & 1.41 & $\mathrm{~S}^{2}{ }_{1}=\mathrm{S}^{2}{ }_{2}$ & 1.813 & 1.584 & $\bar{X}_{1}=\bar{X}_{2}$ \\
\hline Fig. 9:2-3 & 5.19 & 1.07 & $\mathrm{~S}^{2}{ }_{1}=\mathrm{S}_{2}{ }_{2}$ & 1.833 & -3.229 & $\bar{X}_{1} \neq \bar{X}_{2}$ \\
\hline Fig. 9:3-4 & 5.19 & 3.06 & $\mathrm{~S}_{1}^{2}=\mathrm{S}_{2}^{2}$ & 1.833 & -0.560 & $X_{1}=X_{2}$ \\
\hline
\end{tabular}

The columns 2, 3 and 4 pertain to the testing of the variance equality hypothesis; the final conclusion is that rejecting the hypothesis $\mathrm{S}_{1}{ }_{1}=\mathrm{S}_{2}{ }_{2}$ is unsubstantiated. The columns 5, 6 and 7 pertain to the testing of the means equality hypothesis; the statement $\mathrm{m}_{1}=\mathrm{m}_{2}$ means that there is no substance to reject such a hypothesis.

\section{CONCLUSIONS}

The testing to determine the influence of the thickness of bonded elements on the lap length in bonded single-lap joints of the aluminium alloy sheets of different systems, as well as pertaining to the strength of the analysed joints with the statistical analysis of the results, gave the following conclusions:

1. When bonding aluminium alloy sheets of different thicknesses, it is favourable to assume the lap lengths determined for the thinner of elements included in the bonded joint; these joint variations achieve the highest strength (in the specific variants), which is confirmed by test work with the 2024-T3 and 7075-TO aluminium alloys; however, the statistical analysis of the results proved that in the case of the bonded joints of the 7075-TO aluminium alloy sheets there are no statistically significant differences between the results (see Fig. 5).

2. The comparison of the bonded joint strength of varying sheet thickness, with the lap length defined for the thinner and thicker elements, to the bonded joint strength of equally thick sheets with their respective bonded joint lap length showed that the higher strength was exhibited by the bonded joints with a non-uniform thickness of bonded elements (with the provision of different lap length variants); the results of the statistical analysis confirmed this conclusion in the case of the 2024-T3 aluminium alloy sheets, while the bonded joints of the 7075-TO aluminium sheets (which displayed insignificant differences in the results) did not exhibit statistically significant differences at the assumed confidence level;

3. The analysis of the bonded joints made of the same types of aluminium alloy sheets of different thickness, along with their corresponding bonded joint lap lengths, and the analysis of the joints of different aluminium alloy sheet types show the positive influence of bonding the same types of materials with different element thickness with respect to the strength;

4. The analysis of the $27 \mathrm{~mm}$ lap length (determined for the thickness of $0.80 \mathrm{~mm}$ ) assumed for various joint variants shows that it is favourable for the bonded strength of the 2024-T3 aluminium alloy sheets of different thickness (the tested lap length was intermediate); this length was the least favourable for the bonded joints made with the use of 2024TO and 7075-T3 aluminium alloy joints; the statistical analysis of the research results confirms these conclusions;

5. The analysis of the lap length of $30 \mathrm{~mm}$ (determined for the largest sheet thickness tested) revealed that the highest strength was achieved for the different variants of the 2024-T3 aluminium alloy sheet bonded joints (i.e. both 
different and equal sheet thickness), while the lowest strength was displayed with the 7075TO aluminium alloy sheets (also in different variants);

6. It was also noted that the strength achieved was higher for the bonded joints of the 2024$\mathrm{T} 3$ aluminium alloy sheets in different variants than for the bonding joints of the 7075TO alloy; one possible factor for this was the geometric structure of the surface of the tested sheets, which is more favourable strength for the 2024-T3 aluminium alloy sheets;

7. The analysis of bonded joints of the elements of different thicknesses revealed that larger differences in the thickness of the bonded elements, i.e. the larger difference of the bonded joint lap length, greater differences occur in the achieved strengths. In the case of bonding the 2024 aluminium alloy sheets, the difference in the thickness of the bonded elements is $0.34 \mathrm{~mm}$, the difference in the analysed lap lengths is $6 \mathrm{~mm}$ and the strength difference is $26 \%$. In the case of the 7075-TO aluminium alloy sheets, the differences are respectively: thickness $-0.2 \mathrm{~mm}$, lap length $-3 \mathrm{~mm}$, strength $-16 \%$; however, the majority of different variants of joints of these sheets show no statistically significant between the results.

The results were achieved for the bonded joints of aluminium alloy sheets with the given thickness values (which were included in the determination of the bonded joint lap length) and with the right conditions for manufacturing bonded joints. It was noted that the method of assuming the bonded joint lap length is critical for the bonding of materials of different thickness. The lap length determined for the thinner of the bonded element should be assumed to favour higher strength. This conclusion specifically pertains to the 2024-T3 aluminium alloy sheets, since there are statistically significant differences between the values. As for the 7075 aluminium alloy sheets, the assumed sheet thickness has little significance for the determination of the bonded joint lap length. The statistical analysis did not reveal any statistically significant differences in the achieved strengths at the given lap length, depending on the assumed sheet thickness and the confidence level of 0.95 . The analysis of the bonded joints of the 2024-T3 aluminium alloy sheets reveals a positive impact of joining the same types of materials with nonuniform thickness of elements with respect to the achieved strength.

The presented research results are a part of the currently conducted research into hybrid joints. These results and conclusions may be significant in the design of bonded joints, especially of hybrid systems.

\section{REFERENCES}

1. Adams R.D., Comyn J., Wake W.C.: Structural Adhesive Joints in Engineering Book, 2nd edition, Springer 1997.

2. Ebnesajjad S.: Adhesives Technology Handbook, 2nd edition, William Andrew Publishing USA, 2008.

3. Habenicht G.: Applied Adhesive Bonding. A Practical Guide for Flawless Results, WILEY-VCH Verlag GmbH\&Co. KGaA, Weinheim 2009.

4. Megson T.H.G. Aircraft Structures for Engineering Students, $4^{\text {th }}$ edition. Elsevier Science Publishers 2007.

5. Grant L.D.R., Adams R.D., da Silva L.F.M.: Experimental and numerical analysis of T-peel joint for the automotive industry. Journal of Adhesion Science and Technology, 23, 2009, 23, 317-338.

6. You M., Yan Z.-M., Zheng X.-L., Yu H.-Z., Li Z.: A numerical and experimental study of gap length on adhesively bonded aluminum double-lap joint. International Journal of Adhesion and Adhesives, 27, 2007, 696-702.

7. Critchlow G.W., Yendall K.A., Bahrani D., Quinn A., Andrews F.: Strategies for the replacement of chromic acid anodizing for the structural bonding of aluminium alloys. International Journal of Adhesion and Adhesives, 26, 2006, 419-453.

8. Arenas J.M., Narbón J.J., Alía C.: Optimum adhesive thickness in the structural adhesives joint using statistical techniques based on Weibull distribution. International Journal of Adhesion and Adhesives, 30, 2010, 160-165.

9. Godzimirski J.: Wpływ czynników konstrukcyjnych i technologicznych na wytrzymałość połączeń klejowych. Przegląd Mechaniczny, 13, 2003, 18-22.

10. Godzimirski J.: Czynniki kształtujące wytrzymałość połączeń klejowych. Technologia i Automatyzacja Montażu, 4, 1994, 61-64.

11. Godzimirski J., Kozakiewicz J., Łunarski J., Zielecki W.: Konstrukcyjne połączenia klejowe elementów metalowych w budowie maszyn. Oficyna Wydawnicza Politechniki Rzeszowskiej, Rzeszów 1997. 
12. Taib A.A., Boukhili R., Achiou S., Gordon S., Boukehili H.: Bonded joints with composite adherends. Part I. Effect of specimen configuration, adhesive thickness, spew fillet and adherend stiffness on fracture. International Journal of Adhesion and Adhesives, 26, 2006, 226-236.

13. Zhao X., Adams R.D., da Silva L.F.M.: A new method for determination of bending moments in single lap joints. International Journal of Adhesion and Adhesives, 30, 2010, 63-71.

14. Grant L.D.R., Adams R.D., da Silva L.F.M.: Effect of the temperature on the strength of adhesively bonded single lap and $\mathrm{T}$ joints for the automotive industry. International Journal of Adhesion and Adhesives, 2009, 29, 535-524.

15. Rudawska A.: Wybrane zagadnienia konstytuowania połączeń adhezyjnych jednorodnych i hy- brydowych. Monografia. Wydawnictwo Politechniki Lubelskiej, Lublin, 2013.

16. Kuczmaszewski J.: Fundamentals of metal-metal adhesive joint design. Printed by Lublin University of Technology, Polish Academy of Sciences, Lublin Branch Lublin, 2006.

17. http://www.aerospacemetals.com/aluminum-distributor.html (June 2011)

18. http://en.investa.pl (December 2014)

19. http://www.kbhakord.pl (December 2014)

20. http://www.loctite.co.uk (December 2014)

21. http://tds.loctite.com (December 2014)

22. Praca zbiorowa pod red. pod red. P. Konieczki i J. Namieśnika: Ocena i kontrola jakości wyników pomiarów analitycznych. WNT, Warszawa 2007.

23. http://pl.wikisource.org (February, 2015) 